\title{
O zmianach w zakresie leczniczych środków zabezpieczających na tle nowelizacji kodeksu karnego z 2015 roku
}

\author{
ANNA MusZYŃSKA \\ Katedra Prawa Karnego Materialnego \\ Uniwersytet Wrocławski
}

Poszukiwania teoretyczne dotyczące prawnokarnych regulacji w zakresie leczniczych środków zabezpieczających trafiają na grunt zmieniającej się kodyfikacji karnej, zawierającej nowe w tym obszarze propozycje rozwiązań normatywnych. Wyłaniają też poglądy akcentujące nadrzędny cel środków zabezpieczających, to jest ochronę przed sprawcami zagrażającymi porządkowi prawnemu, realizowany przez izolację, a w dalszej kolejności przez leczenie, lecz eksponujące także, w określonym ujęciu, znaczenie elementu leczniczego ukierunkowanego na usunięcie kryminogennych właściwości sprawcy czy też wyraźnie ukazujące tendencje przyznania, w niektórych sytuacjach, w ramach prawa karnego leczeniu i rehabilitacji prymatu przed represją.

Nowelizacja obowiązującego kodeksu karnego, dokonana ustawą z dnia 20 lutego 2015 r. ${ }^{1}$, wprowadziła gruntowne zmiany w układzie środków zabezpieczających, czyniąc go z założenia bardziej uporządkowanym i obejmującym w pierwszej kolejności całkowicie zmodyfikowany katalog środków, określającym następnie zasady ich stosowania, kategorie sprawców, wobec których można stosować środki zabezpieczające, czas stosowania środków, obowiązki związane z poszczególnymi wolnościowymi środkami, unormowania szczególne odnoszące się do środka zabezpieczającego w postaci pobytu w zakładzie psychiatrycznym, podstawy stosowania środków zabezpieczających, które swą treścią odpowiadają środkom karnym określonym $\mathrm{w}$ art. 39 pkt $2-3$ k.k. ${ }^{2} \mathrm{~W}$ nowym ujęciu do środków zabezpieczających zaliczono elektroniczną kontrolę miejsca pobytu, terapię,

${ }^{1}$ Ustawa z dnia 20 lutego 2015 r. o zmianie ustawy — Kodeks karny oraz niektórych innych ustaw, Dz.U. z 2015 r. poz. 396, która weszła w życie 1 lipca 2015 r.

2 J. Majewski, Kodeks karny. Komentarz do zmian 2015, Warszawa 2015, s. 347 n. 
terapię uzależnień, pobyt w szpitalu psychiatrycznym. W porównaniu z uprzednią regulacją wzbogacono katalog o dwa nowe środki: elektroniczną kontrolę miejsca pobytu oraz nakaz określony $\mathrm{w}$ art. 39 pkt 2e k.k., zrezygnowano natomiast ze środka w postaci umieszczenia sprawcy w zakładzie karnym, w którym stosuje się szczególne środki lecznicze lub rehabilitacyjne. Istotnym modyfikacjom poddano też unormowania dotyczące środków związanych ze stosowaniem terapii i terapii uzależnień. Zmiany polegały przede wszystkim na nadaniu większości środków zabezpieczających wolnościowego charakteru i wzmocnieniu w ich treści podobieństw do środków probacyjnych. Środki te można orzekać tylko wówczas, gdy jest to konieczne, aby zapobiec ponownemu popełnieniu przez sprawcę czynu zabronionego, a inne środki prawne, przewidziane w kodeksie lub przepisach innych ustaw, nie będą wystarczające do osiągnięcia tego celu.

Wprowadzeniu nowych regulacji, jak zwykle, towarzyszy potrzeba pogłębionego dyskursu na temat charakteru środków zabezpieczających, ich funkcji czy też umiejscowienia w systemie prawa karnego, a także analizy szczegółowych unormowań ${ }^{3}$. Dostrzegalny jest również pewien dystans odnośnie do praktycznej realizacji nowych środków zabezpieczających. Rozległość zakresu tematycznego powoduje jednak, iż trudnym zadaniem jest komplementarne ujęcie wielości polemicznych wątków wyłaniających się na tle nowego układu środków zabezpieczających. Koncentrując się zatem na wybranych zagadnieniach, warto zwrócić uwagę na jeden ze środków zabezpieczających, a mianowicie terapię uzależnień, tym bardziej, że znajduje ona zastosowanie wobec licznej kategorii sprawców uzależnionych od alkoholu lub szeroko rozumianych środków odurzających. Wybór zagadnienia wydaje się tym bardziej uzasadniony, że już wstępny wgląd w unormowania dotyczące stosowania terapii uzależnień nasuwa wniosek, że ustawodawca nie ustrzegł się błędów i wyraźnych niespójności w zakresie jednorodzajowych regulacji prawnych.

Rozwiązania dotyczące terapii uzależnień zdawać się mogą co do zasady udane, gdyby nie zestawić ich z możliwością zobowiązania do terapii osób uzależnionych od środków odurzających według rozwiązań ustawy z 2005 r. o przeciwdziałaniu narkomanii ${ }^{4}$ czy — idąc dalej — z obowiązkiem leczenia z uzależnienia, nakładanym na osoby uzależnione od alkoholu według art. $72 \S 1$ pkt 6 k.k. jako warunek probacyjny. Dostrzec można wówczas ewidentną niespójność regulacji w zakresie stosowania terapii wobec osób uzależnionych od alkoholu i osób uzależnionych od narkotyków, pogłębiającą się jeszcze w zależności od stosowania kary izolacyjnej bądź kary nieizolacyjnej.

Wyrażając sygnalizowane wątpliwości, tytułem rysu historycznego przypomnieć wypada, że środki zabezpieczające o charakterze leczniczym stosowane

3 Zob. m.in. A. Barczak-Oplustil, Środki zabezpieczajace, [w:] Nowelizacja prawa karnego 2015. Komentarz, red. W. Wróbel, Kraków 2015, s. 671-774.

4 Ustawa z dnia 29 lipca 2005 r. o przeciwdziałaniu narkomanii, Dz.U. z 2016 r. poz. 224. 
wobec uzależnionych sprawców przestępstw znane są w systemie polskiego prawa karnego, poczynając od kodeksu karnego z 1932 r. ${ }^{5}$ Kodeks jako jeden ze środków przewidywał umieszczenie w zakładzie leczniczym osób wymagających leczenia odwykowego (art. 82 k.k.). Przesłanką uzasadniającą zastosowanie środka było dopuszczenie się przez sprawcę czynu naruszającego prawo w związku z nadużywaniem napojów wyskokowych lub innych środków odurzających. Przyjmowano istnienie takiego związku zarówno wówczas, gdy sprawca działał pod bezpośrednim wpływem środków, jak również gdy jego zachowanie było wynikiem pośredniego ich oddziaływania. Związek z nadużywaniem alkoholu lub innych środków odurzających uzasadniał zastosowanie środka zabezpieczającego, gdy istniało realne zagrożenie ponownego ich nadużycia i popełnienia kolejnego przestępstwa. Zgodnie z przyjętą regulacją najpierw należało wykonać orzeczoną wobec sprawcy karę, dopiero potem umieścić go w odpowiednim zakładzie leczniczym. Sąd na podstawie opinii lekarzy specjalistów oceniał, czy pozostawanie sprawcy na wolności po odbyciu kary zagrażało porządkowi prawnemu, i czy umieszczenie w zakładzie leczniczym jest konieczne. Długość trwania środka zabezpieczającego określano na czas nieprzekraczający dwóch lat, przyjmując, iż jest on wystarczający do odzwyczajenia się od nałogu. Uwzględniano jednak wypadki, kiedy leczenie w krótszym czasie przynosiło pozytywne rezultaty i sąd mógł zarządzić wcześniejsze zwolnienie skazanego, które miało charakter bezwarunkowy. Przedstawione założenia dotyczyły zarówno alkoholików, jak i narkomanów, nie przewidywano odrębnych sposobów postępowania wobec tych kategorii sprawców.

Kodeks karny z 1969 r. ${ }^{6} \mathrm{w}$ art. $102 \S 1$ utrzymał środek zabezpieczający polegający na umieszczeniu w zakładzie leczenia odwykowego nałogowych alkoholików i osób uzależnionych od środków odurzających. Podstawę do wydania orzeczenia o zastosowaniu tego środka stanowił związek istniejący między popełnionym przestępstwem a nałogowym używaniem alkoholu lub innego środka odurzającego. Związek ten przyjmowano podobnie jak na gruncie wcześniejszego unormowania, gdy przestępstwo zostało popełnione pod wpływem środków odurzających przez sprawcę dotkniętego nałogiem, jak i wówczas gdy nałóg był przyczyną jego popełnienia. Stosowanie środka było fakultatywne. Umieszczenie w zakładzie leczenia odwykowego następowało przed odbyciem kary, co stanowiło novum w stosunku do poprzedniej regulacji. Sąd nie określał z góry czasu pobytu w zakładzie, nie mógł on jednak przekraczać 2 lat ani trwać krócej niż 6 miesięcy. Przed zwolnieniem z zakładu sąd na podstawie wyników leczenia rozstrzygał, czy należy wykonać orzeczoną karę. Gdy osoba uzależniona w chwili czynu znajdowała się w stanie ograniczonej poczytalności, a jej pozostawanie na wolności groziło poważnym niebezpieczeństwem dla porządku prawnego, sąd mógł orzec

5 Rozporządzenie Prezydenta Rzeczypospolitej z 11 lipca 1932 r. — Kodeks karny, Dz.U. $\mathrm{Nr} 60$, poz. 571 .

${ }^{6}$ Ustawa z dnia 19 kwietnia 1969 r. — Kodeks karny, Dz.U. Nr 13, poz. 94 ze zm. 
jej umieszczenie w szpitalu psychiatrycznym albo w innym odpowiednim zakładzie, nie określając z góry czasu pobytu. W razie skazania na karę ograniczenia wolności wykonanie kary następowało po zwolnieniu z zakładu, natomiast przy orzeczonej karze pozbawienia wolności sąd rozstrzygał, czy należy ją wykonać.

Wraz z wejściem w życie kodeksu karnego z 1997 r. ${ }^{7}$ pojawiły się zupełnie nowe i znacznie rozbudowane, w porównaniu z kodeksem karnym z 1969 r., rozwiązania dotyczące leczniczych środków zabezpieczających stosowanych wobec osób uzależnionych, które w rezultacie dotyczyły osób uzależnionych od alkoholu, z wyłączeniem osób uzależnionych od narkotyków, z uwagi na regulacje lex specialis ustawy o przeciwdziałaniu narkomanii. Kodeks karny z 1997 r. wprowadził możliwość modyfikacji sposobu wykonywania leczniczego środka o charakterze izolacyjnym poprzez przekształcenie go w nałożenie obowiązku kontynuacji leczenia $\mathrm{w}$ formie ambulatoryjnej, połączone $\mathrm{z}$ wyznaczeniem okresu próby. Z tym momentem lecznicze środki zabezpieczające stosowane wobec osób uzależnionych przestały mieć charakter wyłącznie izolacyjny, albowiem pojawiły się środki o wolnościowym charakterze, mające pod wieloma względami charakter środków probacyjnych. Według kodeksu karnego z 1997 r. w stosunku do przestępców, którzy zostali skazani za przestępstwo popełnione w związku z uzależnieniem od alkoholu lub innego środka odurzającego na karę pozbawienia wolności bez warunkowego zawieszenia jej wykonania, przewidziana była możliwość zastosowania przed skierowaniem do wykonania kary pozbawienia wolności środka w postaci umieszczenia sprawcy w zamkniętym zakładzie leczenia odwykowego, o ile zachodzi wysokie prawdopodobieństwo ponownego popełnienia przez niego przestępstwa związanego z uzależnieniem, a orzeczona kara pozbawienia wolności nie przekraczała 2 lat. W przypadku umieszczenia w zamkniętym zakładzie leczenia odwykowego pobyt sprawcy, zaliczany zresztą na poczet kary, nie mógł przekraczać 2 lat, a zarazem nie mógł trwać krócej niż 3 miesiące i był warunkowany wyłącznie wynikami leczenia. W zależności od postępów leczenia sąd mógł skierować sprawcę na leczenie ambulatoryjne lub rehabilitację w placówce leczniczo-rehabilitacyjnej (leczenie w systemie otwartym) na okres próby od 6 miesięcy do 2 lat, stosując równocześnie dozór kuratora, osoby godnej zaufania lub organizacji społecznej. Punktem wyjścia do zastosowania leczenia w warunkach wolnościowych było w każdym przypadku wcześniejsze umieszczenie sprawcy w zamkniętym zakładzie leczenia odwykowego, chociażby pobyt ten miał ograniczyć się do minimum, tj. 3 miesięcy. Pomyślny przebieg okresu próby, w którym, a także w ciągu dalszych 6 miesięcy, nie zarządzono ponownego umieszczenia sprawcy w zakładzie leczenia odwykowego albo w zakładzie karnym, powodowało uznanie kary za odbytą z upływem okresu próby.

${ }^{7}$ Ustawa z dnia 6 czerwca 1997 r. — Kodeks karny, Dz.U. z 2016 r. poz. 1137 ze zm. 
Zawarte w kodeksie karnym z 1997 r. regulacje dotyczące leczniczych środków zabezpieczających stosowanych wobec osób uzależnionych do czasu wielkiej nowelizacji z 2015 r. nie znajdowały zastosowania wobec osób uzależnionych od środków odurzających. Obowiązująca ustawa z 2005 r. o przeciwdziałaniu narkomanii w zakresie uregulowanym w art. 71 ust. 3-5 u.p.n. wyłączała zastosowanie art. 96-98 k.k. z 1997 r. (art. 74 u.p.n.).

Przed 1 lipca 2015 r. stosowne przepisy kodeksu karnego z 1997 r. i ustawy z 2005 r. o przeciwdziałaniu narkomanii, dotyczące tej problematyki, skonstruowane były w taki sposób, iż pod wieloma względami stwarzały wrażenie całkowicie osobnych, niepowiązanych z sobą regulacji. Proces ten został pogłębiony nowelizacją z 20 lutego 2015 r., która gruntownie zmieniła cały system środków zabezpieczających określonych w rozdziale IX kodeksu karnego.

W ustawie z 2005 r. o przeciwdziałaniu narkomanii pozostał w niezmienionej postaci środek zabezpieczający, przewidziany w art. 71 ust. 3-5 u.p.n. oraz instytucja o charakterze probacyjnym, przewidziana w art. 71 ust. 1-2 u.p.n. Obowiązująca ustawa z 2005 r. o przeciwdziałaniu narkomanii, zmieniając szereg szczegółowych regulacji, pozostała przy modelu leczniczego środka zabezpieczającego, wzorowanym w zasadzie na rozwiązaniach kodeksu karnego z 1969 r. Zgodnie z art. 74 u.p.n. w zakresie uregulowania szczegółowego ustawy o przeciwdziałaniu narkomani ${ }^{8}$ nie stosuje się środków zabezpieczających określonych w art. 93a $\S 1$ pkt 1-3 kodeksu karnego (elektronicznej kontroli miejsca pobytu, terapii, terapii uzależnień; pozostaje pobyt w szpitalu psychiatrycznym) w odniesieniu do sprawców, o których mowa w art. 93c pkt 5 kodeksu karnego w razie skazania za przestępstwo popełnione w związku z uzależnieniem od alkoholu, środka odurzającego lub innego podobnie działającego środka.

Ustawa nowelizacyjna z 20 lutego 2015 r. wprowadziła do kodeksu karnego wolnościowy środek zabezpieczający, o którym mowa w art. 93a pkt 3, w postaci terapii uzależnień, który to środek może być stosowany w oparciu o podstawy określone w art. 93b k.k. wobec osób wymienionych w art. 93c pkt 5 k.k., a którego treść określa art. 93f § 2 k.k. Środek zabezpieczający w postaci terapii uzależnień można orzec tylko wówczas, gdy jest to konieczne, aby zapobiec ponownemu popełnieniu przez sprawcę czynu zabronionego, a inne środki prawne przewidziane

8 W wyniku nowelizacji z 2015 r. uchylono stosowanie art. 96-98 k.k. z 1997 r., przy czym nie zmodyfikowano art. 74 u.p.n., który wyłączał stosowanie uchylonych przepisów k.k. W konsekwencji dokonania nowelizacji przepisów rozdziału IX kodeksu karnego oraz braku jakiejkolwiek nowelizacji przepisów ustawy o przeciwdziałaniu narkomanii, a przede wszystkim braku nowelizacji art. 74 u.p.n., powstała sytuacja niepewności prawnej, którą według niektórych teoretyków należało traktować jako uchylenie stosowanych przepisów ustawy o przeciwdziałaniu narkomanii z wszystkimi tego konsekwencjami. Taki stan rzeczy obowiązywał od 1 lipca 2015 r. do 15 kwietnia 2016 r. Art. 74 zmieniony został przez art. 16 ustawy z dnia 11 marca 2016 r. o zmianie ustawy Kodeks postępowania karnego oraz niektórych innych ustaw (Dz.U.2016.437), zmieniającej ustawę o przeciwdziałaniu narkomanii z dniem 15 kwietnia $2016 \mathrm{r}$. 
w kodeksie lub przepisach innych ustaw nie będą wystarczające dla osiągnięcia tego celu (art. 93b $§ 1$ k.k.). Środek zabezpieczający w postaci terapii uzależnień może znaleźć zastosowanie wobec sprawców w razie skazania ich za przestępstwa popełnione w związku z uzależnieniem od alkoholu, środka odurzającego lub innego podobnie działającego środka. Przybliżając istotę tego środka, wskazać należy, że w stosunku do wcześniej obowiązujących przepisów nie zmieniono jego przesłanki podmiotowej odnoszącej się do stanu psychofizycznego sprawcy, tj. stanu uzależnienia. Odmiennie natomiast określono substancje, które wywołują stan uzależnienia. W art. 93e pkt 5 k.k. podano, że chodzi o uzależnienie od alkoholu, środka odurzającego lub innego podobnie działającego środka, eliminując $\mathrm{w}$ ten sposób wątpliwości terminologiczne związane $\mathrm{z}$ uprzednią regulacją, której interpretacja prowadziła do błędnego wniosku, iż z prawnego punktu widzenia alkohol należy traktować jako środek odurzający. Z zakresu przedmiotowego wynika, że sprawca, wobec którego orzeczono terapię uzależnień, ma obowiązek stawiennictwa we wskazanej przez sąd placówce leczenia odwykowego w terminach wyznaczonych przez lekarza i poddania się leczeniu uzależnienia od alkoholu, środka odurzającego lub innego podobnie działającego środka. W kodeksie karnym użyto określenia „placówka leczenia odwykowego”. Nazewnictwo tego rodzaju nasuwa wątpliwości wynikające chociażby z tego, że w systemie prawa w zakresie leczenia uzależnień mamy do czynienia z podmiotami leczniczymi. Powstaje więc pytanie, o jakiej placówce leczenia odwykowego mowa w kodeksie — czy to pojęcie jest równorzędne z podmiotem leczniczym, czy wymaga autonomicznej wykładni. Z przepisu nie wynika też, w jakiej formie terapia uzależnień ma być realizowana. Przyjąć należałoby zatem, że sąd, orzekając środek, wskazuje, czy terapia uzależnień powinna mieć charakter stacjonarny, czy ambulatoryjny. Wnioskować można, że przed podjęciem decyzji sąd uzyska odpowiednią opinię biegłego, albowiem zgodnie $\mathrm{z}$ art. 354a $\S 1$ pkt 1 kodeksu postępowania karnego przed zastosowaniem środka zabezpieczającego, o którym mowa $\mathrm{w}$ art. 93a $\S 1$ pkt 3 k.k., sąd ma zawsze obowiązek wysłuchania psychologa, a w sprawach osób uzależnionych ma możliwość (fakultatywnie) wysłuchania biegłego w przedmiocie uzależnienia. Środek zabezpieczający w postaci terapii uzależnień ma charakter wolnościowy i może być stosowany w przypadku orzeczenia każdej kary. W razie skazania sprawcy na karę pozbawienia wolności bez warunkowego zawieszenia jej wykonania, karę 25 lat pozbawienia wolności lub karę dożywotniego pozbawienia wolności środek ten stosuje się po odbyciu kary lub warunkowym zwolnieniu. W takiej sytuacji nie wcześniej niż na 6 miesięcy przed terminem odbycia kary lub przewidywanego udzielenia warunkowego przedterminowego zwolnienia sąd musi ustalić potrzebę wykonania orzeczonego środka zabezpieczającego. Wiąże się to z tym, że skazani odbywający karę pozbawienia wolności, będący osobami uzależnionymi od alkoholu, środków odurzających lub substancji psychotropowych, mają zgodnie z art. 117 kodeksu karnego wykonawczego obowiązek podda- 
nia się leczeniu w trakcie odbywania kary. Może okazać się zatem, że wykonanie środka zabezpieczającego w postaci terapii uzależnień stanie się bezprzedmiotowe.

Porównując analizowany środek ze środkiem zabezpieczającym z art. 71 u.p.n., przypomnieć należy, że według ustawy z 2005 r. o przeciwdziałaniu narkomanii (art. 71 ust. 3) w razie skazania osoby uzależnionej za przestępstwo pozostające w związku z używaniem środków odurzających lub psychotropowych na karę pozbawienia wolności bez warunkowego zawieszenia jej wykonania sąd może orzec umieszczenie sprawcy przed wykonaniem kary w odpowiednim podmiocie leczniczym na okres nieprzekraczający dwóch lat. Jeżeli skazany nie poddaje się leczeniu i rehabilitacji albo dopuszcza się rażącego naruszenia regulaminu podmiotu leczniczego zwolnienie może nastąpić także na wniosek podmiotu. Po zakończeniu leczenia i rehabilitacji sąd rozstrzyga, czy orzeczoną karę pozbawienia wolności należy wykonać. Ustawa z 2005 r. o przeciwdziałaniu narkomanii przewiduje też (art. 71 ust. 1), że w przypadku skazania osoby uzależnionej za przestępstwo pozostające w związku z używaniem środków odurzających lub psychotropowych na karę pozbawienia wolności, której wykonanie warunkowo zawieszono, sąd zobowiązuje skazanego do poddania się leczeniu i rehabilitacji w podmiocie leczniczym. Przy stosowaniu wskazanego środka pominięta została przesłanka zgody oskarżonego na podjęcie leczenia. Nadto ustawa w zakresie uregulowanym w kodeksie karnym eliminuje możliwość orzekania środków zabezpieczających (elektronicznej kontroli miejsca pobytu, terapii, terapii uzależnień; pozostaje pobyt w szpitalu psychiatrycznym) w odniesieniu do sprawców uzależnionych od środków odurzających.

Nowy środek zabezpieczający w postaci terapii uzależnień (art. 93a pkt 3 k.k.) oparty jest na innych założeniach niż środek przewidziany w art. 71 ust. 3-5 ustawy o przeciwdziałaniu narkomanii. O ile ten pierwszy jest środkiem wolnościowym, który może być orzekany w przypadku każdej kary przewidzianej przez kodeks karny, pod warunkiem że spełnione są wskazane wyżej przesłanki, to rozwiązanie z ustawy o przeciwdziałaniu narkomanii opiera się wciąż na dawnym modelu.

Z powyższego wynika, że przepisy kodeksu karnego dotyczące środków zabezpieczających stosowanych wobec uzależnionych sprawców przestępstw stosuje się jedynie do sprawców uzależnionych od alkoholu, a do takich samych sprawców uzależnionych od środków odurzających lub innych podobnie działających środków stosuje się przepisy ustawy o przeciwdziałaniu narkomanii. W rezultacie mamy nieuzasadnioną odmienność sposobu traktowania tych dwóch kategorii sprawców. Przy wszystkich odmiennościach uzależnień od alkoholu i narkotyków nie ma powodu, aby wobec uzależnionych od alkoholu stosować wolnościowe środki zabezpieczające, a wobec uzależnionych od narkotyków — środki izolacyjne, i to w o wiele węższym zakresie ${ }^{9}$.

9 K. Krajewski, Środki zabezpieczające o charakterze leczniczym stosowane wobec sprawców przestępstw uzależnionych od alkoholu, środków odurzających i substancji psychotropowych, 
Rażące rezultaty daje również porównanie możliwości orzekania środka zabezpieczającego w postaci terapii uzależnień obok kary pozbawienia wolności z warunkowym zawieszeniem jej wykonania do możliwości nałożenia na sprawcę w okresie próby obowiązku probacyjnego poddania się terapii uzależnień zgodnie z art. $72 \S 1$ pkt 6 k.k. przy warunkowym zawieszeniu wykonania kary pozbawienia wolności. Sytuacja będzie przedstawiała się odmiennie w przypadku osób uzależnionych od alkoholu i w przypadku osób uzależnionych od środków odurzających. Przesłanki dotyczące nakładania obowiązku poddania się terapii uzależnień przy warunkowym zawieszeniu wykonania kary pozbawienia wolności na podstawie art. 72 k.k. odnoszą się wyłącznie do sprawców uzależnionych od alkoholu. Do sprawców uzależnionych od środków odurzających stosuje się przywołane powyżej reguły z art. 71 ust. 1 ustawy o przeciwdziałaniu narkomanii. Ten ostatni przepis stanowi lex specialis w stosunku do przepisu art. $72 \S 1$ pkt 6 k.k. Różnica pomiędzy rozwiązaniami kodeksu karnego i ustawy o przeciwdziałaniu narkomanii polega na tym, że zgodnie z art. $72 \S 1$ pkt 6 k.k. nałożenie obowiązku poddania się terapii uzależnień jako warunku zastosowania środka związanego z poddaniem sprawcy próbie w postaci warunkowego zawieszenia wykonania kary pozbawienia wolności ma fakultatywny charakter, a nałożenie takiego obowiązku wymaga zgody skazanego. Natomiast według regulacji art. 71 ust. 1 ustawy o przeciwdziałaniu narkomanii nałożenie obowiązku poddania się leczeniu i rehabilitacji ma charakter obligatoryjny i nie wymaga zgody skazanego. Przepis ten wprowadza także obligatoryjność oddania skazanego w okresie próby pod dozór kuratora, co na gruncie przepisów kodeksu karnego ma jedynie fakultatywny charakter. Kolejna różnica między obowiązkami nakładanymi w przypadku warunkowego zawieszenia wykonania kary a środkiem zabezpieczającym w postaci terapii uzależnień polega na tym, że orzekając środek zabezpieczający, o którym mowa w art. $93 f$ § 2 k.k., sąd ma obowiązek wskazać placówkę leczenia odwykowego, w której skazany ma poddać się terapii. Takiego wymogu nie zawierają przepisy: art. $72 \S 1$ pkt 6 k.k., art. 71 ust. 1 ustawy o przeciwdziałaniu narkomanii. Przepisy te wskazują jedynie na obowiązek poddania się terapii uzależnień albo leczeniu i rehabilitacji w odpowiednim podmiocie leczniczym. Sąd nie ma jednak obowiązku wskazywania placówki, w której terapia miałyby się odbywać, co z kolei jest elementem orzekania środka zabezpieczającego. Takie ukształtowanie przepisów nie znajduje racjonalnego uzasadnienia i rodzi postulat usunięcia tego swoistego dualizmu oraz przyjęcia jednolitej regulacji dotyczącej orzekania terapii uzależnień przez wyeliminowanie wskazanych powyżej różnic.

Oddziaływanie na przyczynę zachowań patogennych związanych z uzależnieniem przesądza o walorach stosowania środków o charakterze leczniczym, które w przyjętym kształcie pozwalają z jednej strony chronić społeczeństwo przed

[w:] System Prawa Karnego, t. 7. Środki zabezpieczajace, red. L.K. Paprzycki, Warszawa 2015, s. 352. 
uzależnionymi sprawcami przestępstw, z drugiej — wywierają wpływ na samego sprawcę poprzez korygowanie jego zaburzeń. Przedstawione rozwiązania wskazują pożądany kierunek zmian w podejściu do leczenia odwykowego, wymagają jednak interwencji ustawodawcy na poziomie wskazanych powyżej regulacji szczegółowych.

\section{On changes in the scope of therapeutic precautionary measures against amendment to the Penal Code of 2015}

\section{Summary}

The author presents questions related to the change in the legal regulations concerning selected precautionary measures. She emphasizes the inconsistencies relating to changes in the scope of precautionary measures, especially addiction treatment. The author basically welcomes the changes resulting from the amendment of 20 February 2015, but considering the need to change specific normative solutions concerning addiction therapy.

Keywords: crime, precautionary measure, addiction therapy, intoxicant, addiction. 